Studies in the Philosophy of Sociality 12

Tiziana Andina

Petar Bojanić Editors

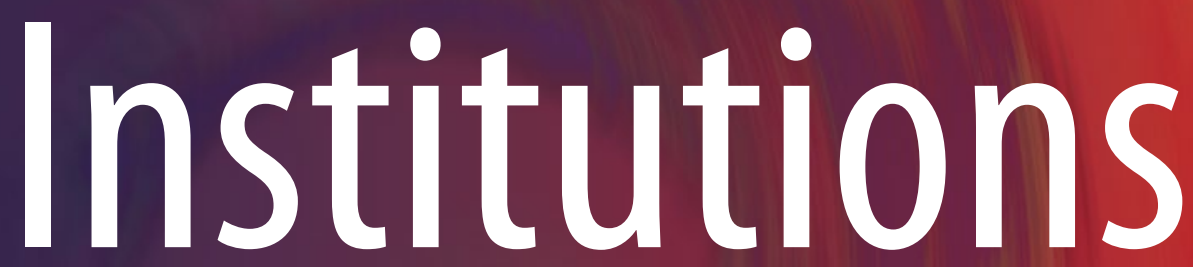

in Action

The Nature and the Role of Institutions in the Real World 


\section{Contents}

1 Social Corporations as Social Institutions $\ldots \ldots \ldots \ldots \ldots \ldots \ldots$. 1 Raimo Tuomela

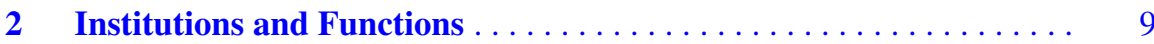
Francesco Guala and Frank Hindriks

$3 \quad$ Epistemic Virtues of Institutions . . . . . . . . . . . . . . . . 21 Snježana Prijić Samaržija

4 What Is an Act of Engagement? Between the Social, Collegial and Institutional Protocols. Petar Bojanić

5 Play It by Trust: Social Trust, Political Institutions and Leisure .... 51 Nebojša Zelič

6 Individual Morality and the Morality of Institutions ............ 73 Thomas M. Scanlon

$7 \quad$ States and Transgenerational Actions....................... 89 Tiziana Andina

8 From Capital to Documediality . . . . . . . . . . . . . . . . . 107 Maurizio Ferraris

9 The Basis of European Cooperation . . . . . . . . . . . . . . . . 123 Jonathan Wolff

10 Ways of Compromise-Building in a World of Institutions . . . . . . . 135 Emmanuel Picavet

Index...................................... 147 


\title{
Chapter 4 \\ What Is an Act of Engagement? Between the Social, Collegial and Institutional Protocols
}

\section{Petar Bojanić}

\begin{abstract}
Engagement is not synonymous with commitment, even though both words are used in translations between English, French, and German. However, engagement is also not some supplementary phenomenon or a technical term that the phrase social acts already includes in itself or that the concepts of 'commitment' or 'joint commitment' somehow necessarily imply. In this article I would like to describe a special kind of social act and determine the function they have in relation between various agents. Most importantly, I would like to define their significance in the transformation of a group into an institution or higher order entity. My premise is that there are acts whose aim is to engage all others, since they refer to all of us together, and in so doing reduce negative (social) "acts" as well as various asocial behaviors within a group or institution. In this sense, engaged acts could alternatively also belong to a kind of institutional act, since they introduce certain adjustments to the institution, changing or modifying its rules, increasing its consistency and efficiency.
\end{abstract}

Keywords Institution $\cdot$ Engagement $\cdot$ Commitment $\cdot$ Social act $\cdot$ Negative social act

I would like to describe a special kind of social acts and attempt to determine the function they have in relation between various agents and most importantly define their significance in the transformation of a group or social group into an institution or higher order entity. My premise is that there are acts whose aim is to engage others or all others, since they refer to all of us together, and in so doing reduce negative

\footnotetext{
P. Bojanić $(\bowtie)$

Institute for Philosophy and Social Theory, University of Belgrade, Belgrade, Serbia

Center for Advanced Studies, University of Rijeka, Rijeka, Croatia

e-mail: bojanic@instifdt.bg.ac.rs; bojanic@cas.uniri.hr
} 
(social) "acts" as well as various asocial behaviors within a group or institution. In this sense, engaged acts could alternatively also belong to kinds of institutional acts, since they introduce certain adjustments to the institution, changing or modifying its rules, increasing its consistency and efficiency.

Engagement is not synonymous with commitment, even though the two words are used in translation between English, French, and German. ${ }^{1}$ However, engagement is also not some supplementary phenomenon or a technical term that the phrase social acts already includes in itself or that the concepts of 'commitment' or 'joint commitment' somehow necessarily imply. Let me begin by sketching the nature of neglect and diminishment of importance of the verb 'to engage' (or 'engagement' or 'act of engagement'). Here is a list of a few basic characteristics of this specific protocol in relation to others, such as social, collegial, and committed acts:

(a) Both engagement and commitment refer to the will ("commitmentof the will" [Gilbert 2013: 899]), but engagement explicitly assumes the transfer or import of certain burden or amount of burden that can then be compared to other similar engaged acts. Engagement is never the same as some other engagement, and the quantity of the burden (gage, pledge) always determines its efficiency and success, as well as strength of bond to some future actions that the engagement could initiate. This quantitative characteristic (e.g. amount of enthusiasm and will to perform some task or introduce or change a rule) has resulted in the verb 'to engage' becoming the condition for an action or simply preceding some following action ("The engagement of the agent is already needed before acting" [Toumela 2013: 121] "[...] they had indeed engaged in some acts" [Johnson 1973: 403]). If person P is engaged to be a manager of a company (to conduct certain business acts and make decisions), then the same person P could be very engaged at their new job. They would, in that case, produce many, rather than few, various acts, which could be described as engaged and be called acts of engagement. Engagement of person $\mathrm{P}$ at their new job could then incite other agents-coworkers to also engage and follow the engagement of person $\mathrm{P}$ in their own activities. In that sense, person $\mathrm{P}$ would not produce acts that 'engage no one' (the French equivalent of this would be ' $n$ 'engage à rien'), that is to say, acts that leave others indifferent; yet, we could not say that these acts necessarily bind all other agents to follow the enthusiasm of person P. The act of engagement would therefore be one to which another act is joined, which it follows without obligation or coercion. ${ }^{2}$

\footnotetext{
${ }^{1}$ Although 'commitment' is now often not translated at all into European languages, Howard S. Becker's text or Margaret Gilbert's 'commitment' are translated as 'engagement'. While in the opposite direction, Sartre's or Adorno's 'engagement' is translated into (American) English as 'commitment'. Cf. Becker $(1960,2006)$, Gilbert (2003: 15). 'Joint commitment' is translated into French as 'engagement conjoint' (Gilbert 2003: 152) and not as, for example, co-engagement, which would be much more straightforward.

${ }^{2}$ Let me offer two comments regarding the act. In "On Promises," Georg Henrik von Wright insists, in an entirely Aristotelian manner, that "the act cannot be performed solo. It requires two parties, (for example) promise-giver and promise-receiver. They are human beings. (...) When a promise is given collectively or jointly by several agents, or when a promise has more than one receiver, it seems that these cases are essentially similar to the simpler case" (Von Wright 1962: 287). In his "L'Acte symbolique," Émile Bréhier defines the efficiency of an act with the possibility of it being interchangeable with another act or whether its author can be another subject: "l'acte est impersonnel" (Bréhier 1917: 350). In Theory of Constitutional Rights, Robert Alexy defines acts "as those which cannot be performed merely on the basis of natural abilities, but which presuppose constitutive rules." (Alexy 2002 [1986]: 152)
} 
(b) If the term 'engagement' describes several or more "acts of engagement" then these acts should be frequent and directed at the same goal ("consistent line of activity"3). Both engagement and commitment share this characteristic because both protocols allow acts to issue and follow one another. Person P, engaged or committed to the new position of management, for example, produces acts that we can describe as strongly dedicated to the goal or task before them. It would appear as if person P no longer has a choice "and must continue the line of action, whether she is personally committed to it or not."4 If after a period of time the commitment of person $\mathrm{P}$ is relegated because the promises, agreements, contracts or duties of person P surpass their personal preferences and enthusiasm ("she must continue the line of action"), I assume that the characteristic of engagement of person P on the contrary, still surpasses the obligations it has accepted and tasks to which they have agreed.

(c) Commitment and engagement could be separated in the following manner: as a matter of fact, person $\mathrm{P}$ has been committed by the board or some committee to perform the job of the manager, much as person $\mathrm{P}$ has the capacity or authorization to commit or delegate various coworkers in the job at hand. Thus, person $\mathrm{P}$ has been committed to do something, and in turn this person has the "right to demand of someone a certain action,"5 to give command and thus obligate others. In that sense commitment is a chain operation that puts together multiple actors (committere; Zusammentun or zusamensetzen) ${ }^{6}$ in several ways: by each individually, through an act, places themselves under an obligation, by one who has a mandate to obligate others by command, fulfilling in that way an obligation given to them or ordered by someone else. Person $\mathrm{P}$ could be committed to performing act A (or person $\mathrm{P}$ could commit person $\mathrm{S}$ to performing act A). But also, person $P$ could engage such that their actions are not at all obligating and are not in accordance with 'commitment'. For example, person $\mathrm{P}$ attempts to improve the system as they encountered it in the new company and thus begins a quality improvement project that is outside their task description. This action has resonated and intrigued person $\mathrm{S}$ and they have decided to join. Regardless that with person S's act of 'joining' person P has certainly created a certain normative order and an obligation between them (joining is also the condition for their joint action that Gilbert names as joint commitment), I nevertheless insist that this pseudo-obligation is purely temporary and can always be broken by either side (which is why I call it engagement and not [joint] commitment). ${ }^{7}$ It is the reciprocal response and

\footnotetext{
${ }^{3}$ Both Becker (1960: 33) and Johnson (1973: 395) underscore this basic characteristic of commitment.

${ }^{4}$ Johnson (1973: 395) differentiates personal and behavioral commitment.

'It is 'commitment' (and not 'joint commitment') in its medieval uses that explicitly assumes of someone to do something. For Margaret Gilbert, however, 'joint commitment' is ground of 'right' to demand of one to do something or "a right against another person has the standing to demand a particular action from that person." (Gilbert 2018: 11).

${ }^{6}$ Französisches Etymologisches Wörterbuch (1966 [1922]: 955).

${ }^{7}$ Gilbert's interventions over the years have rendered the phrase 'joint commitment' rather vague. It seems to me that the reconstruction and introduction of the term engagement (along with related terms such as 'act of engagement') could in one way or another correct and pin down the meaning of joint commitment. Joint commitment would first of all be a semi-pleonasm as it only emphasizes one of the meanings commitment already carries within itself. Nearly 20 years ago, Gilbert introduced the phrase 'relevant joint commitment' that implies successful joint commitment if the actors, paradoxically, are more engaged or if they act in a specific way. "(...) people who can engage in joint activity;" or " (...) acting together as stemming from a prior agreement to engage in the relevant joint action;" or again "only if a certain condition is satisfied will he or Lily be committed through the relevant joint commitment." (Gilbert 2014: 24, 26, 47) The problems only multiply in her book Rights and Demands: A Foundation Inquiry, in the chapter "The Ubiquity of Joint Commitment" (2018: 218-232) where the meaning of joint commitment is expanded and
} 
answered call on behalf of person S (their engagement) to the action of person $\mathrm{P}$ that determines whether person $\mathrm{P}$ is indeed conducting engaged acts or not. Some conditions for person $\mathrm{S}$ to 'be moved' and then potentially join the common action (and not be 'joined' to it, that is, that there is no entity that decides) would be that person P publicly and transparently manifests their own goals, that they are of general interest or in the interest of all (members of the company, but also of the public at large). And when these acts are conducted jointly, when the reciprocal responses are joined $(\mathrm{P}+\mathrm{S}+\ldots)$, there is necessarily a change in the institution (company, organization, city, etc.).

Let us now consider a few more uses of the word 'engagement', to which we usually pay no attention or consider unimportant enough to specifically thematize. In a few places in "Valuing [the] Interpersonal. Relationships and Acting Together" (which mostly follows the 2007 German version "Interpersonelle Bezeihungen und gemeinsame Handlungen"), Betzler renders the French or French-German word Engagement into English as 'engagement'. She also adds it ('engagement' and not 'commitment') in a few places to the English in comparison to the German. For example:

A friendship or a band's jazz improvisation can become a valuable engagement only if the participating persons relate to each other reciprocally (wenn sich die daran beteiligten Personen in besonderer und noch näher zu charakterisierender Weise wechselseitig aufeinander beziehen). (Betzler 2008: 259; 2007: 445)

Engagement, then, is, or engagement (as a condition, evidently) exists, when several persons are in question (not only one) and they "relate to each other reciprocally." In the forthcoming manuscript "Collegial Relationships" (which Betzler has graciously allowed me to consult), Betzler and Löschke mention this word nine times, e.g. "person who engages in the same business" or "kind of engagement for a common purpose," etc. On page 13, we find the following formulation:

Work relationship between colleagues is characterized by ongoing interactions that two colleagues engage in because of the relation that holds between them. These interactions are limited to the context of those features that constitute the status of colleagues, but they are enduring, orientated towards the other as colleague, rooted in a shared history and marked by shared expectations for future thoughts and actions. Two colleagues thus establish a relationship by actualizing interconnected but temporal chains of behavior.

In addition to a common goal ('business' or 'common purpose'), and individual action that is also simultaneous or reciprocal to those of others, a chain sequence of actions in a time to come, the first sentence of this passage indicates that in engagement / commitment, some kind of relation exists among colleagues (a kind of 'primordial we'), which in this case precedes their engagements. Or else, these

surpasses promises, agreements and contracts (although it still retains normative power; it is unclear how this is possible) and where all intersubjective relations are reduced to joint commitment.

${ }^{8}$ In the English version, Betzler mentions several times, "the valuable engagement" and connects it with "reciprocal interpersonal reference." On page 261 of the English edition, Betzler writes: "In order to realize such engagements at all, the act of referring to others has to be valued for its own sake. But what turns valuable engagements of the kind mentioned into interrelational values is the fact that, in order to be realized, the participating persons must refer to each other reciprocally and for the sake of their relationship's own value." 
colleagues are 'engaged' by the interaction because it holds them together, which is termed 'relation' ("relation of collegiality"). If the first text presents engagement through simultaneous, above all reciprocal, actions, the other text makes engagement a consequence of something already given in advance through a "relation of collegiality." And the guarantor or source of the latter is, for example, the institution (such as the university). Even if this second were the case, it seems to me there is no collision if we conclude that "valuable engagement" between colleagues will be one in which they "relate to each other reciprocally" and which simultaneously conducts the process of institutionalization (e.g., confirms the institution of the university and the rule of collegial communication). If colleagues conduct themselves institutionally or with collegiality or if they produce engagement acts, then this means that they "relate to each other reciprocally." Based on observations found in texts here cited, it is still uncertain whether 'engagement' is an act or condition, and of what kind of 'reciprocity' we are speaking, given that engagement always begins with a certain asymmetry and stimulative activity or increased attention in relation to other actors. ("She, Martina is more engaged in the association to fight cancer from Martin," or with the reciprocal response, "Martin has changed and become much more active and dynamic, working much more - Martina and Martin are now a real team or tandem." $)^{9}$ Further, it is uncertain whether engagement is part of what Adolf Reinach or Edmund Husserl call a "social act" (in the sense of a step or degree a social act can but does not necessarily have to contain - at issue is the rule of reciprocity) or is it actually an entirely special case of social acts whose function would be to institutionalize a group, to convert a group into an institution.

What then is a social act? In the brief sketch "Nichtsoziale und soziale Akte,"10 Reinach offers a very deft definition of social acts, and summarily rejects and excludes everything not in the definition by calling it "nichtsoziale Akte" (which then functions as irrelevant refuse, that is to say, anything not a social act is not a social act - there should be no new special entity entitled nichtsoziale Akte). ${ }^{11}$ But

\footnotetext{
${ }^{9}$ Explaining in 1711 who Hercules was, the Earl of Shaftsbury says (in "A Notion of the Tablature, or Judgment of Hercules"): "He admires, he contemplates; but is not yet ingag'd or interested." Cf. Berger, 2011: 36. In an English-German dictionary of 1763, the word 'ingagement' is translated as verbinden or anreizend.

${ }^{10}$ Nichtsoziale Akte is Reinach's phrase, which he mentions only in passing, in a short 1911 text (really a reconstruction of his lecture notes from Göttingen). The text was only published for the first time as part of his collected works (Reinach 1989a, b). Reinach never explicitly explains what are Nichtsoziale Akte (in the notes they are mentioned two or three times as opposite from social acts), nor indeed do almost any of his commentators.

${ }^{11}$ In a few steps, entirely in rhythm with Reinach's chapter on social acts, we can classify their difference from negative social acts: a social act is spontaneous (a negative is not). Spontaneity designates inner actions of the subject (innere Tun des Subjektes). A social act is not at peace in itself; it demands to be externalized (a negative not). A social act penetrates another (er dringt in den anderen ein), while the negative does not. A social act can be perceived, a negative cannot. A social act has an inner and external (phenomenal) aspect; negative acts only the inner. The expression of a social act is not accidental or inadvertent, while the negative one is. A social act can have many addressers and addressees (Soziale Akte können eine Mehrheit von Adressanten und eine Mehrheit von Adressaten haben), the negative cannot (Reinach 1989a, b: 158-161).
} 
right on the heels of this definition, he suddenly calls into question his own distinction with the example of prayer.

The appearance form exists only because among us people things are such that we can only know our inner acts (unsere inneren Akte) by way of their appearance forms (Erscheinnungsformen). Prayer (das Gebet), for example, is a social act (ist ein sozialer $A k t$ ). The first [therein] exists, while the second not (it has no apparent form). The religious man assumes that the addressee hears the prayer without the apparent form (ohne Erscheinungsform vernimmt). Thus, a silent prayer is also possible (Darum ist also ein stilles Gebet möglich). (Reinach 1989a: 357)

Prayer $i s$ (the ist in the original is italicized) ${ }^{12}$ a social act because regardless of the uncertainty of existence of one who hears the prayer (here I follow Reinach's realism) and with whom there is really no connection, there is, nevertheless, an inner act or experience, as well as an addressee of whom one who prays (the religious man) assumes not only the existence but acceptance of what is being sent (even if the believer sends nothing, that is, a series of unuttered words from a familiar protocol). In his book, however, Reinach reworks and enhances this "prayer" scene:

Let us imagine a community that comprises beings capable of directly and immediately perceiving their mutual experiences. We would be forced to admit that in such a community, there very well could appear social acts that possess only soul, but no body. If we assume that a being to which we address ourselves in our social acts is capable of directly grasping our experience, we humans would in that way truly renounce the outward appearance of our social acts. Remember that silent prayer addresses God and seeks to manifest itself to him. It thus must be seen as a purely spiritual social act. ${ }^{13}$

\footnotetext{
${ }^{12}$ Reinach makes generous use of italics, while Husserl, around the same time (1910), in constituting social ontology and descriptive sociology in Zur Phänomenologie der Intersubjektivität (Hua, $13,1)$, insists on the use of the quotation marks. All the themes we have today in social ontology are already present in Husserl, but in an unsystematic way, in contrast with a few developed texts by Reinach. I would like to insist, regardless of the hesitations they have in common, that (a) there is an obvious influence of Husserl on Reinach, but also a contemporaneity - Husserl himself quite early discusses acts of address or communicative acts, and also "acts," orders, acts of love, the unity of social life based on mutual and unilateral exchange (der Einheit eines sozialen Lebens, mit aktiver und reaktiver Wechseleinigung oder einseitiger Bezogenheit), and further conduct of a higher unity by way of acts that produce mutual consciousness of the actors $(\mathrm{Hua}, 13,1)$ (Husserl 1973a: 98). (b) I would also like to insist on Reinach's resistance to Husserl's empathy and affection. (c) Husserl explicitly speaks of linguistic acts and a linguistic community, but in an entirely different and insufficiently focused way compared to Reinach. Later, Husserl opens the possibility of the existence of consciousness or cogito of a superpersonal unity. (d) Husserl is probably one of the first social ontologists who is aware of the importance of the document, of the ID (Ausweisung). (Hиа, 13, 1) (1973a: 104) (e) Husserl neglects Reinach in his notes after the war (around 1920) when he speaks in detail of social acts.

13 "Denken wir uns eine Gemeinschaft von Wesen, die imstande sind, ihre gegenseitigen Erlebnisse direkt und unmittelbar wahrzunehmen, so werden wir anerkennen müssen, dass in einer solchen Gemeinschaft soziale Akte, welche nur eine Seele und keinen Leib besitzen, sehr wohl vorkommen können. So verzichten wir Menschen in der Tat darauf, unsere sozialen Akte in äussere Erscheinung treten zu lassen, sobald wir annehmen, dass das Wesen, an welches wir sie richten, unser Erleben direkt zu erfassen vermag. Man denke an das stumme Gebet, welches sich an Gott wendet und sich ihm kundzugeben tendiert, welches demnach als ein rein seelicher sozialer Akt betrachtet werden muss." (Reinach 1989a, b: 161)
} 
The sentence "Let us imagine a community that comprises beings (Wesen) capable of directly and immediately perceiving their mutual relations," as perhaps one of the crucial places of Reinach's chapter on social acts, demands certain entirely different and more complicated examples from that of a religious person addressing an invisible addressee through prayer. And not only examples, but also, analogously, collectively engaged activity that would indeed turn non-social into social acts, or else entirely eliminate them. ${ }^{14}$ If we imagine a community in which negative social acts are eliminated in mutual interaction, ${ }^{15}$ then this would call into question one of the most important distinctions between social and non-social acts Reinach produced: a social act can have many addressers and addressees (Soziale Akte können eine Mehrheit von Adressanten und eine Mehrheit von Adressaten haben); a negative one, on the other hand, cannot.

In contrast with his student, Husserl neither recognizes nor accepts any forms of asymmetry or non-reciprocity between social actors. Even when experimenting several times in notes taken later in life with the possibility for empathy to also be truly reciprocal and active, Husserl still rejects such an idea because I cannot see whether the other notices me simultaneously, whether they are observing themselves, that is, whether they are at all interested in me when I am directed at them. In order for true communicatio to take place (Husserl uses the Latin ${ }^{16}$ ), my activity needs to be explicitly declared and reciprocated (actively oriented towards me) ${ }^{17}$ Husserl insists on the word activity (Aktivität), directedness and project (Vorhabe), and insists on the will for something to be explicitly declared (Wille der Kundgebung) to the other (or others) as the main conditions for the social and communicative unity to take place (soziale, kommunikative Einigung).

Husserl first insists (very early, around 1910) that intersubjective relations are in themselves real and that the individuals who conduct them are real (reale Individuen) (Hua, 13, 1) (1973a: 96-97). Further, acts, communicative acts (kommunikative Akte), "acts addressed to others" (die sich an den Anderen wenden) imply that the

\footnotetext{
${ }^{14}$ One of the foremost characteristics of engaged acts is the elimination of the negative, unengaged, non-social, anti-social acts (if they are acts at all). In "Negative "Actions"' Gilbert Ryle calls into question these acts as acts ("if they are acts"). Namely, negative actions (refraining, abstaining, postponing, shirking, neglecting, disobeying, overlooking, condoning, etc.) "is the class of acts which consist in the agent's intentional non-performance of some specifiable actions" (Ryle 1973).

${ }^{15}$ In St. Märgen, in 1921 Husserl develops "communal acts" or "acts in a social community" (Gemeinschaftsakte, Handlungen in der sozialen Gemeinschaft). Cf. Hua, 14, 2. (Husserl 1973b: 192-205). In April of 1932, Husserl speaks of various forms of linguistic expression and the expectation that the one to whom we have addressed a message answers, and of the disappointment if the answer goes missing. In order to receive an answer, it is necessary to give silence to one or those of whom we expect a response, which in a way is also a negative act. Hua, 15, 3 (Husserl 1973c: 474-475).

${ }^{16}$ In saying so, Husserl is really saying that "communication creates unity" (Kommunikation schafft Einheit) (Hua, 14, 2) (1973b: 199).

17 "Ein Besonderes ist es nun, dass ich ihn verstehe als vice versa auf mich aktiv und explizit auf meine Bekundugen, auf meine darin bekundete Aktivität gerichtet" (Hua, 15, 3) (Husserl 1973c: 472).
} 
other is aware that they are being addressed (in denen der Andere bewusst ist als der, an den ich mich wende). The other needs to understand the address from which certain acts have been sent and respond with an act of the same kind (zurückwenden wird in einem gleichartigen Akte). "These are acts that produce a higher unity of consciousness of person to person (...)" (Das sind die Akte, die zwischen Person und Person eine höhere Bewusstseinseinheit herstellen) (Hua, 13, 1) (Husserl 1973a: 98). The third characteristic of social acts I would like to point out here, and which Husserl ingeniously develops, refers to the norm of the community (eine Gemeinschaftsnorm) or joint norm. Husserl finds that social acts are actually not norms that force, but rather that they are pseudo-norms or pseudo-obligations: ${ }^{18}$ "it is a common willing regulation (eine Einheit der Willensregelung), acknowledged by individuals and is a super-individual (ïberindividuell). (...) One who does not respond to a salutation, who does "not thank" is a lout (ein Flegel). (...) if I address someone politely, I have the right (Ich habe ein Recht) to expect a polite response from them, that is thanks as response to the polite salutation, etc." (Hua, 13, 1) (Husserl 1973a: 105-106). ${ }^{19}$

In Freiburg in 1921, Husserl attempts one more perspective: he negates or eliminates social acts which are not social acts or not yet social acts. First, love, my love or admiration is not yet a social act of any kind. If I love, this is not yet an act of social love (Akte der sozialen Liebe). If I do something deliberately for another to notice and behave in a way that I am myself displaying - none of this is yet a social act. It is a social act if I do something hoping that the other, noticing my intention, will respond in their way (Hua, 14, 2) (Husserl 1973b: 166). ${ }^{20}$ In the same year, Husserl discovers something else new by analyzing the family. He demonstrates how a temporary unit (vorübergehende Gemeinschaft) turns into an orderly institution (geregelten Institution) if its members routinely eat together. Having meals together (social acts) are the basic elements for the institution (der Stiftung) of the family as a social institution (soziale Institution). For a family to be a family (for a 'We' to become an institution) it is insufficient to be side by side, to live next to or

\footnotetext{
${ }^{18}$ This would be another decisive characteristic of engaged acts that is never biding while possessing the capacity of initiating or moving along the linking activity in another or others. In "Commissives," a chapter in his most important book, John Austin explains the protocols ('engage' and 'pledge' are some of them) that are not binding - such as 'promise' - yet could still "commit you to doing something, but include also declarations or announcements of intentions." A statement that commits the speaker to some future action simultaneously performs two functions: on the one hand, it prevents 'omissions' and negative acts, and on the other, engages the audience who are supposed to respond to the speaker in one way or another (Austin 1975: 152, 156-158).

${ }^{19} \mathrm{~A}$ toast could be a still better example that would shed light on what I call an engaged act. It is not a matter of my right to expect anyone to respond, nor is it a matter of right of the person not to respond. It is, rather, a gage or a pledge that engages (burdens) another when I salute them with a toast, one I always feel as unease: I invite someone to do something they otherwise (perhaps) would not do and the unease since they might not respond in equal measure to my invitation.

${ }^{20}$ For a social act to be an act there needs to be a chain process, not mimesis. Each next person, each person following an act by someone else confirms that the act is social. If my act engages another whose act in turn engages me or someone third - then my act is social. The sociality of an act is decided by each following act. Cf. Hua, 14, 2 (Husserl 1973b: 193).
} 
near another. "Much more than that, it is a matter of the way of being together, way to be in relation to another, mutually exchanging within living situations (wechselseitige Aufeinander-Bezogenheiten des strebenden Lebe), in acting, in reciprocal influence of one another, in relations that function reciprocally, and based on which the action of one penetrates into the action of the other" (Hua, 14, 2) (Husserl 1973b: 179).

The final characteristic of social acts, as imagined and defined by Husserl, quite probably his greatest discovery, appears suddenly in January 1931, when Husserl names this other (one close to him, with whom he is exchanging acts) as 'the third' (dritte). It seems to me that formulated like this, 'the third' is the premise for the discovery of 'We', that is, of the institutional act. "My neighbor (one close to me), who I now perceive (ansehe), is now already the third (...) who helps in the continuous formation of the world from the initial world-state "for us two," to a world for us three" (Hua, 15, 3) (Husserl 1973c: 134).

This last moment that for Husserl determines the social act opens the question of the nature of reciprocity. If two persons "relate to each other reciprocally," and if we have previously defined this situation as (their) engagement, does their developing and increasing interaction imply the appearance of the third or the group, and then the institution?

Let us return once more to collegial engagement and the institution (the university). An interesting scene (a possible analogy) appears in the introduction of the recently published book by Francesco Guala, Understanding Institutions:

If I look to the right, I see my colleague Antonio reviewing a paper for a scientific journal. On the left, a map of China hangs on the wall. In front of me, past the door of my office, two students are walking in the corridor of the Department of Economics. Out of the window, I can see the second floor of the Faculty of Social Science of the University of Milan. (...) Antonio, for example, is a colleague of mine because we are both employees of the same university, and the University of Milan is an institution. (Guala 2017: XII)

Gilbert Ryle describes a foreigner (that is what he calls him) visiting Oxford or Cambridge, hopelessly seeking the institution of the university. Finally, he asks, "But where is the University?" (Frank Hindriks also has a text, from 2012, with this same title). I am interested in Antonio, the colleague ("Antonio, for example, is a colleague of mine because we are both employees of the same University") who is performing an institutional activity ("reviewing a paper for a scientific journal"). It only seems that Francesco Guala is merely describing Antonio (it does not look like they are really doing something together); the fact is that Antonio produces institutional or academic acts par excellence because, as an employee of the university, he is performing an action the university as a group agent has formulated as its goal. ${ }^{21}$ Since Antonio is certainly not only a member of this group-institution (Antonio has,

\footnotetext{
${ }^{21}$ This too could be a basic paraphrasing of the "we-mode" of Raimo Toumela's protocol. "An individual member derives the reasons from which she/he acts from the intentions that the group agent forms. (...) Given that members derive their participatory intentions from the intention of the group agent, the level of the group agent is in an important sense primary and prior to that of an individual member" (Hindriks 2017: 198).
} 
for example, a rather large family, renowned for its production of wine, meaning that Antonio holds shares, he goes bowling at a club called "Inter Sempre," and in his free time is a serious poker player - in fact, he is the president of the Italian association; Milton Friedman insists that we must never forget that we are never members of only one group, which fact has various theoretical and practical consequences). ${ }^{22}$ And since Antonio is a very busy man, Antonio, for example, does not have time to be very engaged as the Vice Dean for International Cooperation of the University of Milan.

Now, my problem, or our problem, begins with a certain Frederique who works at another university, who has not published a text in an academic publication in 30 years, is a few years from retirement, is late with her submission, neglects her lectures, has had some reported incidents with students, in fact she is currently under investigation for harassment, and has poor relations with her fellow colleagues (Bernhard Schmid named all these acts "bad acts" or "evil actions"). ${ }^{23}$ To make matters interesting, the recently elected president of the university, Etienne, a vainglorious jurist and ambitious administrator, has coauthored a paper with Frederique, the theme of which is harassment, and which has received positive feedback for publication. Before we attempt to classify some of these acts - and of course there is always the question what is an act and whether some negative actions are actions at all - it seems important to me to insist right away that the institutional or collegial acts performed by Etienne (such as those towards or in relation to Frederique) are not necessarily the consequence of Etienne's having an institutional mandate or the function of University President. Nor due to Frederique and Etienne's simultaneous belonging to the same entity in which they share potential institutional responsibility. I will call these acts "engaging," above all because they change the institution (alter it but simultaneously create it) by introducing new rules - even if it is sometimes very difficult to develop or differentiate an action or event, an engaged act is one that decidedly creates something new, such as a real event. Thus, a new institutional fact is that now Frederique is "reviewing a paper for a scientific journal." Of course, this new situation could produce a certain form of obligation in all members of a group (and in those who have yet to become so; meaning, it is

\footnotetext{
${ }^{22}$ In a certain way, this "freedom of association" (Kimberley Brownlee) and simultaneous membership in multiple groups always implies disharmony and so-called "moral messiness." Postponing the execution of an obligation undertaken by membership in a group in order to execute a task implied by membership in another group always manifests in "negative actions" or "negative social acts."

${ }^{23} \mathrm{Cf}$. "Where have all those negligent, sloppy, unfocused, forgetful and weak-willed people gone whom we know from real life, all those who for some reason or another fail to do (or even fail to intend to do) their part in their collective projects?" (Schmid 2009: 47) Although "the power of the negative is an important power, and our dissidents and our cultural subversives provide that power" (Annette Baier), we ought certainly to differentiate non-participation in a group and not performing certain tasks from negative activities that directly call into question the group or institution. There are other problems too. Tuomela employs the example of a car that has broken down, with one of those now having to push the vehicle to the side of the road an invalid. All this must not be conflated with so-called "non-cooperative game theory."
} 
imperative to engage all), that is, that they oblige the group as such ("group agent") to form new kinds of obligation. ${ }^{24}$ To be engaged means to count on all others and work so as to produce a great stake or burden (gage, pledge $)^{25}$ that ought to reiterate obligation and institutional responsibility even in those we have labeled hold-outs, subversive or simply 'Frederique(s)'.

Therefore, I insist on there being an entirely imprecise or uncertain number of different unclassified activities that have the capacity to:

(a) not only encourage or activate another (or others) into identical or similar action or reciprocal reaction, but also to produce a pseudo-obligation that implies a joint, group action ("to do something as a group"), and

(b) not only to, so to speak, obligate members of a group to do something together, but to exceed the borders of joint commitment of the group, a priori 'obligating' non-members or all potential and future participants towards joint and coordinated action.

What are these actions like, then, the ones that engage others (all others) or that have the capacity to commit (to bring together, collect and bind even those who are not present in one place simultaneously)? Engaged action would then be one that is above all public or announced (for it cannot be a kind of negative social act or a secret, an undisclosed action performed in silence). Further, it is provocative in nature, really a call or message to all, to others (com-mittere can mean to send), a prompting of all to come closer, to join (not only members of a group, but also those outside and beyond the group), because "to commit" precisely means an action that encourages or obligates others to do something together by doing so as members of a future committee. However, engaged action is specific in that it supposes this type of great or grand work, adherence ("giving one's all" "committed to the end") and abandon (a kind of sacrifice for others or with other or towards others, or in their stead, sacrifice for the sake of bringing closer, but also as work that calls others to join, to repeat our action and thus construct future joint work) - all with the goal of bringing us closer to others. ${ }^{26}$ We advance towards or are brought closer to others,

\footnotetext{
${ }^{24}$ Likely, this is "une obligation librement consentie" [a freely-agreed obligation]. Von Jhering uses a potentially analogous term in 1886, die active Solidarobligation.

${ }^{25}$ Or hostage (hostage). This is one of the most important meanings of the word pledge. More interesting still is the word toast that holds in itself both the call and response to call, as well as the community beyond all obligation. It seems to me that Sartre is wrong when he writes that the group or institution always changes with the introduction of a new member, just as there is no abstract member "without baggage" (sans baggage): "Si vous avez un bagage, vous pouvez vous engager parce que vous-même, vous négocierez. (...) Mais si vous n'en avez pas, vous entrez inconditionnellement dans un groupe, donc pour vous engager il faut que vous acceptiez toutes ses théories." (If you have baggage, you can still be engaged because you yourself negotiate... But if you have none, you join the group conditionally, that is to say, to be engaged, you must accept all its theories) (Astruc 1977: 46).

${ }^{26}$ The word engager comes from the verb vado, with the German word wadi, Latin vas, vadis meaning "je m'avance vers quelqu'un," "I am advancing towards another" (Kemp 1973: 16). Kemp fails to mention a much more interesting meaning of "engagement" that draws this protocol
} 
either when we become bound to them or bind them to us, when we "invest" or "place something" into or before others, when we "mettre en gage" / "pledge" or "donner en gage" / "give a pledge."

What does this mean? What does it mean to place a pledge or burden (guarantee, bail, hypothéque; "engager, c'est hypothéquer") before another or before all (the whole community), and to what extent is that a form of modest violence and forcing others (or all) to choose whether they would join this specific action or not? What kind of action does not principally have to be strictly in direct relation with another ("if I am doing something, then you or he must do likewise"), but that certainly binds me to another (and the other to me) such that it jointly obligates us to conduct it ("if I act, then we all act," "if you act, then all act")? If my public activities involve collecting money for gravely ill children, organizing temporary shelter for war refugees from a neighboring state, or if I often visit slaughterhouses to protest against the (way of) killing animals, would not all these activities be called engaged (and "activist")? Each could represent "personal commitment," and at the same time, none could be performed individually, but would always require smaller or larger groups of people. However, this transformation of individual into group agency need not necessarily be the most significant characteristic of these actions. The beginning of the explanation of this transformation was long ago constructed by Kant, where he speaks of duties to oneself as such (Pflicht gegen sich selbst), of debt or obligation to oneself that always precedes and underpins any possible obligation to others (which he will call external duty).

Far more complicated, but also perhaps more crucial, is the set of actions that could be located in that place in English where two complementary words or strategies overlap and at the same time diverge: engagement and commitment. Personal committed action (crucially perhaps in contradistinction to the French engagement) remains personal, such as me being engaged in my career or caring for the ill. Only a handful of people, in my more or less immediate circle, will recognize this commitment, and in recognizing it might feel that it is "a thing of public importance," and thus an obligation to join in. Commitment or joint commitment, always in the plural, calls for a different kind of obligation. Namely, when I call a lunch meeting of our poker group, or what have you, to a nearby restaurant, and promise to attend the beginning of the meeting, then I am truly committed and all those who answer the meeting call will confirm my action, thus also becoming committed. But the engagement of our group occurs only when the actions of the group produce sufficient reason or some form of obligation for those who do not initially belong to our

fatally close to the words institutere and instituo (institution). Instituetere (einsetzen) is continuation, the production of heir (Französisch Etymologisches Wörterbuch 1966: 724), while Gaffiot says this same thing by insisting on some uses in Cicero that refer to "se créer des amis," and to "continuing" in the sense of "chain-linking" not "repetition" ("continue comme tu as commencée") (Dictionnaire Gaffiot 1934: 833). If several Torino families band together of their own accord to remove trash (as a group), they are calling others to join them ('friends'), to do as they do ('repetition' is really linking and creating a chain of institutional gestures), which further implies the possibility of creation of an alternative counter-institution whose many and diverse actions produce a cleaner city. 
group, or those who are still not at the scheduled meetings, to necessarily join. If our group truly acts together, if it is jointly engaged (such action always referring to the vital connections and relationships that hold the community or the group together), then it would seem I am obligated to join it, to become engaged ("if all act, then I act"). This new, so-called obligation is different from a non-perfect obligation, because the person that gives charity or uses polite protocols or helps the poor in no way produces the identical obligation in me. By contrast, engagement of a group could never leave me indifferent.

These acts obligate and connect above all those who are not yet part of the group or institution, who have yet to become so, yet are nevertheless always present. This is decidedly not the same kind of obligation as exists within an agreement (a result of a promise, money-lending or various other kinds of transactions), nor the obligation of the actor in joint commitment. The cry "help," paradoxically, 'obligates' those who are definitely not present, refers to anyone who hears it, even who has never heard it before. Nor is its imperative force and its "ad hominem capacity" certainly any weaker if it is an individual call or plea: 'help me'. Joint commitment assumes above all an act that implies belonging to a group, such as those who could help (I act, therefore I am an agent, a part of a whole, of all together). Only if I do something publicly, potentially addressing everyone and affirming the existence of all, do I prove the existence of a large group and my belonging to it.

This very act is institutional. Why? Because my help to a migrant or a small group of migrants actually represents a small committed act that necessarily implies a multiplicity of new (engaged) acts that could then further construct systemic institutional help to all migrants (and all future migrants). An institutional act is not necessarily normative ${ }^{27}$ - that I 'have to' help one who is endangered because I so confirm that I belong to an institution whose task it is to provide first aid to ones who need it. An institutional act is also an engaged act that calls for the engagement of all, for the sake of transforming occasional, one-off acts of help into consistent institutional actions, that is, institutional agency.

\section{References}

Alexy, R. (2002). Theory of constitutional rights. Oxford: Oxford University Press.

Astruc, A. (1977). Sartre. Paris: Gallimard.

Austin, J. L. (1975). How to do things with words. Oxford: Oxford University Press.

Becker, H. S. (1960). Notes on the concept of commitment. The American Journal of Sociology, 66(1), 32-40.

Becker, H. S. (2006). Notes sur le concept d'engagement (C. Debras and A. Perdoncin, Trans.). Tracés. Revue de Sciences humaines 11, 177-192.

Berger, B. (2011). Attention, deficit, democracy. The paradox of civic engagement. Princeton: Princeton University Press.

${ }^{27}$ J. R. Cameron $(1971,1972)$ proves that 'has to' and not 'ought to' is substantial for institutional obligations. 
Betzler, M. (2007). Interpersonelle Beziehungen und gemeinsame Handlungen. Deutsche Zeitschrift für Philosophie, 55(3), 441-456.

Betzler, M. (2008). Valuing the interpersonal. Relationships and acting together. In H. B. Schmid, K. Schulte-Ostermann, \& N. Psarros (Eds.), Concepts of sharedness. Essays on collective intentionality (pp. 253-272). Ontos Verlag: Frankfurt.

Bréhier, É. (1917). L'Acte symbolique. Revue Philosophique de la France et de L'étranger, 84, 345-361.

Cameron, J. R. (1971). 'Ought' and institutional obligation. Philosophy, 46(178), 309-323.

Cameron, J. R. (1972). The nature of institutional obligation. The Philosophical Quarterly, 22(89), 318-332.

Französisches Etymologisches Wörterbuch. (1966). Ed. Walther von Wartburg. Vol. II. Basel: Zbinden Druck und Verlag AG.

Gaffiot, F. (1934). Dictionnaire illustré latin-français. Paris: Hachette.

Gilbert, M. (2003). Marcher ensemble. Essais sur les fondements des phénomènes collectifs (B. Auerbach et al., Trans.). Paris: PUF.

Gilbert, M. (2013). Commitment. In H. LaFollette (Ed.), The international encyclopedia of ethics (p. 899). London: Blackwell.

Gilbert, M. (2014). Joint commitment. How we make the social world. Oxford: Oxford University Press.

Gilbert, M. (2018). Rights and demands: A foundation inquiry. Oxford: Oxford University Press.

Guala, F. (2017). Understanding institutions. Boston: Harvard University Press.

Hindriks, F. (2017). Group agents and social institutions. Beyond Tuomela's Social Ontology. In G. Preyer \& G. Peter (Eds.), Social ontology and collective intentionality. Critical essays on the philosophy of Raimo Tuomela with his responses (pp. 197-210). New York: Springer.

Husserl, E. (1973a). In I. Kern (Ed.), Zur Phänomenologie der Intersubjektivität 1905-1920. Den Haag: Martinus Nijhoff.

Husserl, E. (1973b). In I. Kern (Ed.), Zur Phänomenologie der Intersubjektivität 1921-1928. Den Haag: Martinus Nijhoff.

Husserl, E. (1973c). In I. Kern (Ed.), Zur Phänomenologie der Intersubjektivität 1929-1935. Den Haag: Martinus Nijhoff.

Johnson, M. P. (1973). Commitment: A conceptual structure and empirical application. The Sociological Quarterly, 14(3), 395-406.

Kemp, P. (1973). Théorie de l'engagement, Vol. 1 Pathétique de l'engagement. Paris: Seuil.

Reinach, A. (1989a). Nichtsoziale und soziale Akte. In K. Schumann \& B. Smith (Eds.), Sämtliche Werke (Vol. I, pp. 355-360). München: Philosophia Verlag.

Reinach, A. (1989b). Die apriorischen Grundlagen des bürgerlichen Rechtes. In K. Schumann \& B. Smith (Eds.), Sämtliche Werke (Vol. I, pp. 141-278). München: Philosophia Verlag.

Ryle, G. (1973). Negative 'Actions'. Hermathena, 115, 81-93.

Schmid, H. B. (2009). On not doing one's part. Dissidence and the normativity of collective intention. In Plural action: Essays in philosophy and social science (pp. 47-58). Berlin: Springer.

Tuomela, R. (2013). Social ontology. Collective intentionality and group agents. Oxford: Oxford University Press.

Von Wright, G. H. (1962). On promises. Theoria, 28(3), 277-297. 